Nippon Suisan Gakkaishi $\quad$ 81(2), $301(2015)$

\title{
ミニシンポジウム記録クルマエビ栽培漁業の今後を考える
}

\section{5. クルマエビ栽培漁業の発展と今後について}

伏見 浩 福山大学附属内海生物資源研究所

5. Progress and future prospects on stock enhancement of Kuruma prawn HIROSHI FUSHIMI

The Research Institute of Marine Bioresources, Fukuyama University, Onomichi, Hiroshima 722-2101

クルマエビ栽培漁業技術の基礎は南西海区水産研究所 （当時）の倉田博博士をリーダーとした浅海別枠研究に よって築かれた。その後, 各県の栽培漁業センターが整 備されると同時に種苗量産技術開発事業と放流技術開発 事業が国の補助事業として行われた。放流技術開発事業 では種苗の中間育成と放流後の回収率の推定に重きが置 かれた。静岡水試浜名湖分場（当時）は体長組成解析, 標識放流，漁獲曲線解析，操業位置記録，抢よび浜帳整 理に基づいて放流群と天然群の判別を行い，コホート解 析を行って放流群の回収量の推定方法を提案し, 回収率 の推定を行った。1 浜名湖で行われた放流技術開発研究 を概観し，種苗放流の持つ意味を考えたい。また，種苗 放流に基づく栽培漁業が地域社会に果たした役割と，そ れが持続できるために必要な事柄について考えたい。

1. クルマエビ資源の動向と種苗放流 クルマエビの 漁獲量は 1970 年代前半に著しく減少し，1000トン程 度になった。当時は, クルマエビは沿岸漁家にとってき わめて重要であり,これの減少は死活問題であった。こ の減少を契機に，国は栽培漁業を展開することになっ た。当時の瀬戸内海栽培漁業協会がクルマエビの種苗量 産の技術開発に成功し，種苗放流が行われるようになっ た。浅海別枠研究と瀬戸内海各県水試による種苗放流効 果調査が種苗放流の原動力となった。種苗の放流量が増 えるとともに漁獲量は増加し, 年間 3000 トンレベルに まで回復した。しかし，補助事業としての種苗放流が終 わるとともに種苗放流量は激減し，現在ではクルマエビ の年間総漁獲量は 1000 トン以下にまで減少した。

2. 漁獲量減少の理由と Habitat sequence の重要性 瀬戸内海沿岸の埋め立て面積の増加とクルマエビ漁獲量
とに負の相関が認められた。 ${ }^{22}$ 東京湾でも同じ現象のあ ることが報告された。3) クルマエビの生活は, 外海の砂 浜域, 内湾の河口域, それに連続する浅海域，さらには 浮遊幼生の生活域が連続して存在する場で行われる。干 潟と汀線の喪失は, そうした Habitat sequence を断ち 切り，クルマエビの生活を成り立たなくした。種苗放流 の効果が資源造成に結びつくか否かは Habitat sequence の有無にかかっている。クルマエビ種苗の放流 は沿岸域の埋め立てに対する社会的経費とは考えられな いだろうか。

3. 中間育成 孵化場で生産された着底期の稚エビを 放流場所に順応させるために中間育成を行う必要があ る。海面を使用する中間育成成績には種苗の質の良否が 大きく影響する。また, 中間育成成績には密度効果があ る1)ことにも注意を払う必要がある。

4. 放流種苗の適サイズ 放流種苗のサイズは, 放流 場所がクルマエビの生活環のどの部分を支えているかに よって変えなければならない。干潟とそれに隣接する浅 所を利用できる場合の種苗サイズは最も小さくて良い。 水深 4-5 m の場所に放流するのなら, 成熟直前くらい のサイズが望をしいだろう。

5. 種苗放流の社会経済的役割 種苗放流が地域社会 に受け入れられる仕組みについては殆ど検討されていな い。総合地球環境学研究所の東南アジアのエリアケーパ ビリティ（AC）の向上に関する PJ（石川智士リーダー） の中でフィリッピンのウシエビ種苗放流とそれの社会的 影響評価ならびに AC サイクルの評価が行われており， 近い将来に報告されることが期待される。

\section{文献}

1) Fushimi H. How to detect the effect in releasing operation of hatchery raised Kuruma prawn postlarvae? - case study of the operation in the Hamana Lake. Bull. Tohoku Natl. Res. Inst. 1999; 62: 1-12.

2) 土井長之, 岡田圭介, 石橋喜美子. クルマエビ環境要因の 減耗作用の評価一 I, 西条干潟における環境要因の選抜. 東海区水研報 1973; 76: 37-52.

3）今井利為. 神奈川県におけるクルマエビ種苗放流の評価. 神水試研報 1982; 4: 53-62. 